of air by charcoal cooled to the temperature of liquid air.

The second method of showing the absorption of air, due to Dr. L. T. Jones, is at once clear by an inspection of $B$ in the figure. The vertical stem, up to the branch leading to the charcoal bulb, should be at least $78 \mathrm{~cm}$. long. This stem may also have an enlargement about half way up as shown. A valve should be included to protect the charcoal when not in use. Before starting the experiment the valve is opened and the tube mounted in a bath of mercury. Liquid air is then applied to the charcoal bulb. The absorption proceeds slowly at first, but soon gains headway as the charcoal cools. The speed that the mercury column acquires as it rises up through and fills the enlargement is surprising. Even with the ratio of volume of tube to charcoal as shown in the figure (approximately $4: 1$ ) the mercury column will mount to nearly full atmospheric pressure in the short space of five or six minutes.

Added interest is to perform the two experiments simultaneously.

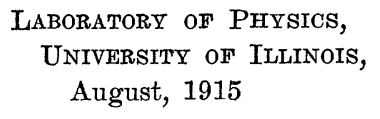

OCCURRENCE OF THE PROTOZOAN, COLACIUM MULTOCULATA KENT, IN IOWA

Is making collections of Daphnia, and other Entomostraca, on October 31, 1914, the writer discovered a small pond near Iowa City, Iowa, which fairly teemed with Daphnia of a striking green color.

Examination of these specimens in the laboratory revealed the cause of the coloration to be myriads of individuals of the Protozoa bearing chromatophores and being attached to the surface of the Daphnia completely covering, not only the body proper, but even the appendages in many cases.

These Protozoa yielded themselves readily to identification as belonging to the genus Colacium-Flagellates closely related to Euglena but differing therefrom in one essential, among others, of having a sedentary attached stage as well as a free-swimming stage. In the sedentary stage the individual zooids are attached by pedicles to some object or, as is more often the case, to some other form of animal life.

Kent (1881) mentions, at the close of his discussion of the Colacium, a supplementary species for which he proposes the provisional name of Colacium multoculata. It is with his description of this species that the animals under the observation of the writer most favor. ably compare.

As with Kent the writer demonstrated a very short pedicle and in no case was more than a single individual found on one pedicle. Ther is a general tendency for the animal to assume a quadrate-elliptical form in outline both when free-swimming and fixed, with an occasional broadening near the distal end. The shape is subject to more or less continual change. The chromatophores are very large and seem to be distributed near the periphery of the cell. Kent describes the presence of from two to four red spots instead of the single one commonly present and from this character proposes the name of the species. By far the most of the specimens examined by the writer possessed but one spot, some half dozen individuals from the many showed from two to four as described. In as much as the differing specimens agreed in all other essential characters they were undoubtedly variations of the same species. The possession of a flagellum by the free-swimming form was amply demonstrated.

Edmondson in his treatise on the Protozoa of Iowa ${ }^{1}$ includes Colacium in his key to genera but states that no species of this genus has been reported within the state. It is probable that other species closely related to the one forming the subject of this note may be added to the list of Iowa Protozoa.

Laboratories of ANIMAL BIology,

\section{M. Brumfied}

State UnIVERsity of Iowa

\section{SPORE MEASUREMENTS}

THe usual way of giving measurements of spores as width by length in $\mu$ is clear and 1 Davenport Academy of Sciences, 1906. 